\title{
Morfologi Bahasa Arab: Reformulasi Sistem Derivasi dan Infleksi
}

\author{
Muhammad Aqil Luthfana, Syamsul Hadi ${ }^{b}$ \\ aUniversitas Islam Negeri Walisongo Semarang \\ bUniversitas Gadjah Mada \\ Corresponding author: aaqilluthfan@walisongo.ac.id
}

\begin{abstract}
Morphology, in the study of Arabic linguistics known as the discipline 'ilm al-șarf, as part of grammar which examines the internal structure of words, has an urgency to be studied in depth. Especially in the context of Arabic studies that embrace typologies of complex inflective languages. This article examines the Arabic morphological system from a modern linguistic perspective, especially on derivational and inflectional changes. The discussion begins on the conception of derivation and inflection in the view of modern linguistics, as an introduction to see the system of derivation and inflection changes in Arabic linguistics. Morphological theories of Arabic grammars, in this article developed and communicated with modern linguistic theories. From this development a new formula was produced in the study of Arabic morphology which is expected to provide a more systematic description of the understanding of the Arabic morphological system.
\end{abstract}

Morfologi, dalam kajian linguistik Arab dikenal dengan disiplin 'ilm al-sharf, sebagai bagian dari gramatika yang mengkaji struktur internal kata, mempunyai urgensi untuk dipelajari secara mendalam. Terlebih dalam konteks kajian bahasa Arab yang menganut tipologi bahasa inflektif kompleks. Artikel ini mengkaji sistem morfologi Arab dari perspektif linguistik modern, khususnya pada perubahan derivasional dan infleksional. Pembahasan dimulai mengenai konsepsi derivasi dan infleksi dalam pandangan para tata bahasawan modern, sebagai pengantar

ISSN 2622-6146 (e) 2622-6138 (p)

(C) 2019 Alsina : Journal of Arabic Studies

http://journal.walisongo.ac.id/index.php/alsina 
untuk melihat sistem perubahan derivasi dan infleksi dalam linguistik Arab. Teori-teori morfologi dari para tata bahasawan Arab, dalam artikel ini dikembangkan dan dikomunikasian dengan teori linguistik modern. Dari pengembangan tersebut dihasilkan satu rumusan baru dalam kajian morfologi Arab yang diharapkan dapat memberikan deskripsi pemahaman sistem morfologi Arab secara lebih sistematis.

Keywords: Arabic linguistics; derivation; 'ilm al-șarf; inflection; theory reformulation.

\section{Pendahuluan}

Intuisi lingual berikut sudah muncul dan terbangun sejak lama mulai dari tradisi klasik sampai studi linguistik modern, bahwa deskripsi gramatika mempunyai garis demarkasi yang memisahkannya menjadi dua bidang utama. Pertama wilayah sintaksis (syntax), secara sederhana dapat dikatakan sebagai studi tentang hubungan antar kata dalam suatu kalimat; dan yang kedua morfologi (morphology), yaitu studi tentang komposisi formal dan semantis dari sebuah kata. Anderson (1985: 150) menyimpulkan divisi ini berimplikasi pada bentuk paralelisasi atau kesejajaran antara dua bidang tersebut. Kalimat terdiri dari rangkaian beberapa kata, dan kata terbentuk dari bagian-bagian yang lebih kecil, sejak periode linguistik tradisional bagian-bagian itu disebut dengan morfem. Akan tetapi nampaklah diferensiasi yang jelas dalam determinasi antara kombinasi kata dan kombinasi morfem dan di sinilah titik demarkasi yang memberikan garis pemisah antara sintaksis dan morfologi itu.

Pada periode awal, linguistik Arab klasik memberikan ruang yang sama antara dua bidang tersebut. Kajian sintaksis Arab dibahas dalam disiplin 'ilm an-nahwu, sementara untuk kajian morfologi dibahas dalam disiplin 'ilm ash-sharf. Kedua disiplin ilmu ini dianggap memiliki relasi yang lekat antara satu dan lainnya, hanya saja Owens (1988:89) menengarai pada periode pasca Sibawaih para tata bahasawan Arab 
memberikan porsi sintaksis yang lebih lebar daripada morfologi dalam sistematika yang acak, misalnya Ibn as-Sarrāj dalam al-Ushūl fĩ an-Naḩw, al-Anbārī dalam Asrār al-'Arābiya, az-Zamakhsyarī dalam al-Mufashshal, Ibn 'Aqīl dalam Syarh Ibn 'Aqīl. Paradigma semacam ini kemudian menjadi mainstream dalam tradisi linguistik Arab tradisional, menjelma menjadi satu sistematika teoritis yang mengangkat dogma prioritas sintaksis di atas wilayah morfologi. Hal ini terbuktikan pada sebagian besar literatur gramatika Arab menempatkan wilayah morfologi pada posisi inferior. Padahal para pelopor linguistik Arab periode klasik sebelumnyamulai akhir abad ke-8 sampai awal abad ke-9-telah membangun satu analisis morfologis yang menakjubkan, yang berbeda dengan teori morfologi modern akan tetapi keduanya sama-sama berkaitan dengan cara yang unik (Ryding 2005: 44).

Mainstream di atas tentunya menimbulkan permasalahan yang tidak sederhana mengingat bahasa Arab sebagai bahasa infleksi sekaligus mengikuti tipologi morfologi disilabis mempunyai implikasi pada struktur sintaksis yang amat dinamis. Berbeda dengan karakter bahasa-bahasa isolasi maupun aglutinasi, kata dalam bahasa Arab mempunyai sensitifitas tertentu terhadap lingkungan yang melingkupinya dalam sebuah kalimat. Morfologi bahasa Arab seperti pandangan Ryding (2005: 44), sangat berbeda dengan tata morfologi bahasa Inggris misalnya atau bahasa Indonesia dalam beberapa hal mendasar, morfologi bahasa Arab mempunyai aturan-aturan yang sistematis; highly sistematic morphology.

Paradigma morfologi semacam ini secara nyata pada taraf sintaksis terbuktikan dalam konsepsi perubahan vowel di akhir kata pada suatu struktur kalimat yang dalam teori Arab dikenal dengan konsep i'rāb. Oleh karenanya dari kaca mata sintaksis ada dua jenis kelompok kata dalam bahasa Arab, 
yaitu kelompok kata inflektif atau mu'rāb jenis kata yang dapat berubah struktur vokal akhirnya dengan menyesuaikan lingkungan sintaksisnya; dan ada kelompok non-inflektif atau mabnī yaitu jenis kata yang memiliki struktur vokal cenderung stabil tidak terpengaruhi oleh lingkungan sintaksis di sekitarnya (Dahīāh, 2001:113).

Jadi dalam gramatika bahasa Arab ada satu peran morfologis yang amat krusial dalam struktur sintaksis. Artinya morfologi Arab memegang peran penting dalam sistem sintaksisnya. Logika sederhananya mengatakan, siapa yang ingin menguasai sintaksis Arab secara efisien dan komprehensif maka sebelumnya ia harus mempelajari sistem morfologinya terlebih dahulu. Ibn Jinnī (1954: 2) yang dikenal sebagai pakar morfologi Arab, menguatkan logika kontramainstream terakhir dengan mengklaim bahwa setiap tata bahasawan dan pemerhati bahasa Arab mutlak membutuhkan penguasaan aspek morfologis ini karena morfologi Arab menurutnya adalah mīzān al-'arabiyah atau parameter bahasa Arab. Senada dengan pendapat ini Ibn 'Ushfūr (1996: 31) juga memandang bahwa aspek morfologi harus dikedepankan dari sintaksis karena morfologi membahas struktur kata, di mana kata berperan sebagai "input" untuk membentuk suatu kalimat dalam struktur sintaksis.

Memang belum diketahui secara pasti siapa yang mempelopori studi morfologi dalam sejarah linguistik Arab dan kapan mulai dikembangkan, disinyalir ada dua tokoh sebagai peletak garis demarkasi antara morfologi dan sintaksis yaitu Mu'ādz ibn Muslim al-Harrā' dari kelompok Kufah (Suyūthī, Tt:400) dan al-Māzinī dari Basrah (Ghanī, 2007: 25). Kemudian Ibn Jinnī mengembangkan dan mengulas konsep al-Māzinī dalam karyanya yang fenomenal dalam wacana teori morfologi Arab, al-Munshif, karya inilah yang mengukuhkan Ibn Jinnī sebagai rujukan primer dalam teori morfologi Arab. Karīm (1991: 411) dalam penelitiaannya 
menyatakan bahwa Ibn Jinnī pada masanya telah banyak mengenalkan konsep-konsep baru yang selanjutnya ditemukan dalam teori morfologi modern, misalnya konsep alwihdah ash-sharfiyah atau satuan morfologi, dan at-tahwill fï ash-shiyagh ash-sharfiyah atau morfologi transformatif.

Fenomena semacam ini semestinya membuka lebar-lebar pintu interaksi antara teori linguistik Arab dengan linguistik modern. Dengan kata lain terbukalah kesempatan untuk mengkaji aspek-aspek gramatika Arab dari perspektif linguistik modern. Sebab sebagai disiplin ilmu yang mempelajari tentang seluk beluk kebahasaan, linguistik umum mempunyai cara pandang universal yang dapat menyentuh aspek-aspek kesemestaan bahasa dan mengkaji dengan mengidenktifikasi pendekatan yang pas, sesuai dengan karakter gramatika bahasa Arab. Apalagi bahasa Arab sendiri sebagai salah satu rumpun bahasa Semit, pada kenyataannya justru amat determinan dalam perkembangan konsep-konsep inti dalam teori morfologi, maka tidaklah berlebihan ketika Ryding (2005:44) mengatakan:

"In fact, Arabic and Semitic languages have had substansial influence on the development of certain key concepts in theorotical morphology."

Sejarah perkembangan gramatika Arab sendiri telah mencatat, betapa banyak inovasi dan cara pandang baru terbuka, pada kurun abad ke-17 sampai abad ke-19, ketika bahasa Arab mulai banyak berinteraksi dengan tata bahasawan non-Arab. Hal ini berbanding lurus dengan sejarah perkembangan disiplin linguistik modern yang waktu itu juga tengah masuk babak awal perkembangannya dalam tradisi historis komparatif. Tepatnya pada tahun 1786 oleh Parera (1991: 54) disebut sebagai tahun "breakthroughs" perkembangan linguistik modern sampai saat ini, ditandai dengan presentasi ilmiah Sir William Jones di hadapan The 
Royal Asiatic Society di Kalkuta tentang silsilah kekerabatan antar bahasa Sansekerta, India Klasik, bahasa Yunani, Latin dan Jerman. Tradisi akademik ini terus berkembang sampai munculnya linguistik struktural atau dikenal dengan linguistik modern yang dipelopori oleh Ferdinand de Saussure pada penghujung abad 19.

Gejala tradisi ilmiah yang cenderung mengglobal seakan menghapus sekat-sekat demografi lingual di setiap penjuru, tidak terkecuali linguistik Arab sebagai salah satu instrumennya. Adalah Thomas Erpenius pada tahun 1636 membukukan karya ilmiahnya, Grammatica Arabica. Killean (1984: 224) mengklaim karya Erpenius ini sebagai "milestone" atau batu lompatan pertama kajian gramatika Arab di Barat. Erpenius di sini mencoba memetakan gramatika Arab dengan model gramatika Latin sehingga terasa familiar dan mudah dipahami oleh masyarakat non-Arab. Pada tahun 1810 dominasi Erpenius di Eropa mulai digantikan oleh tata bahasawan asal Perancis Sivestre de Sacy dengan karyanya Grammaire Arabe. Sampai akhirnya kelompok tata bahasawan non-Arab ini menemukan pendekatan yang lebih suitable dalam karya William Wright pada tahun 1874 dalam karyanya A Grammar of The Arabic Language (Killean, 1984: 227). Pada dekade terakhir ini juga banyak pengembangan lanjutan dari tata bahasawan non-Arab, dalam studi sintaksis misalnya karya Eslsaid Badawi, M. G Carter dan Adrian Guly Modern Written Arabic pada tahun 2004, dan dalam studi morfologi misalnya karya Karin C. Ryding pada tahuan 2005 Modern Standard Arabic yang diterbitkan oleh Cambridge University.

Satu hal yang menggembirakan bahwa perkembangan teori-teori linguistik Arab di perguruan tinggi-perguruan tinggi Timur Tengah akhir-akhir ini juga cukup marak ditandai dengan banyak munculnya para tata bahasawan Arab kontemporer seperti Shubhī Shālih, Ibrāhīm Anīs, Tamām Hasān, Syauqī Dlaif, Ahmad Mukhtār Umar, Muhammad Daud 
dan tata bahasawan lainnya yang sangat produktif memberikan kontribusi perkembangan ilmiah melalui gagasan-gagasan mereka.

Kecenderungan revitalisasi teori gramatika Arab ini patut disambut dengan tangan terbuka, sebab jika tidak, problematika kompleksitas gramatika Arab akan bertemu dengan mainstream skema teori gramatika yang acak, akan memunculkan persepesi konsep lingual yang rumit. Ranah morfologi sebagai bagian dasar gramatika Arab selanjutnya menjadi aspek determinan sebagai titik tolak untuk melihat problematika ini. Sementara morfologi Arab mempunyai sistem yang sangat kompleks, maka dari itu pengkajian sistem morfologi Arab menjadi kebutuhan yang krusial. Semua aturan yang diterapkan dalam morfologi Arab harus dijelaskan secara tuntas dalam sajian yang logis.

Pada tulisan ini penulis mengkaji konsepsi morfologi derivasional dan infleksional, bagaimana penciriannya, dan seperti apa implementasinya dalam morfologi Arab.

\section{Sistem Derivasi dan Infleksi}

Konsensus para tata bahasawan sekali lagi mengatakan bahwa wilayah morfologi secara tradisional memiliki dua konsep bawahan yang terpenting dalam paradigma morfemis; derivasi dan infleksi. Kedua konsep ini seringkali digambarkan sepenuhnya terpisah. Bauer (2001: 73) memilah bahwa infleksi adalah bagian dari sintaksis sedangkan derivasi bagian dari leksis. Infleksi menyediakan variasi bentuk dari sebuah leksem sementara derivasi menyediakan leksem baru. Dalam teori linguistik mutakhir pembedaan ini diindikasikan berimplikasi pada organisasi gramatika. Aturan-aturan morfologi infleksional dipandang sebagai bagian dan mempunyai hubungan dengan wilayah sintaksis sementara aturan derivasional dipandang sebagai bagian dari sistem leksikon atau paling tidak aturan derivasi tidak diterapkan pada wilayah 
gramatikal. Dalam bahasa yang lebih sederhana dapat dikatakan derivasi adalah mengenai bagaimana kata-kata itu dibentuk sementara infleksi mengenai bagaimana kata-kata tersebut berinteraksi dengan sintaksis (Ryding 2005: 44).

Bickford memandang morfologi derivasional sebagai pengambilan satu kata dan mengubahnya menjadi kata lain, yakni menciptakan entri-entri leksikal baru. Dalam kasus yang lebih jelas morfologi derivasional menciptakan suatu bentuk kata dari kategori sintaksis lain. Di pihak lain morfologi infleksional tidak mengubah suatu kata menjadi kata yang lain dan tidak pernah mengubah kategori sintaksis, sebaliknya menghasilkan bentuk yang lain dari kata yang sama (Ba'dulu dan Herman, 2005: 12). Samsuri (1982: 198) melihat morfologi derivasional sebagai sebuah konstruksi yang berbeda distribusinya daripada bentuk dasarnya, sedangkan morfologi infleksional ialah konstruksi yang menduduki distribusi yang sama dengan bentuk dasarnya.

Dalam proses pembentukan kata secara derivatif, identitas leksikal bentuk yang dihasilkan tidak sama dengan identitas leksikal bentuk dasarnya atau dengan kata lain kelompok derivasi adalah perubahan morfologis yang menghasilkan kata dengan identitas leksikal yang berbeda. Sebaliknya dalam pembentukan kata inflektif, identitas leksikal kata yang dihasilkan sama dengan identitas leksikal bentuk dasarnya, atau dapat dikatakan kelompok infleksional adalah perubahan morfologis dengan mempertahankan identitas leksikal dari kata yang bersangkutan (Chaer, 2008: 37).

Permasalahannya adalah apa yang dimaksudkan dengan "identitas leksikal" yang menjadi tolak ukur jenis penggolongan derivatif dan inflektif. Identitas leksikal menurut Verhaar (2008: 118) melingkupi dua aspek; yaitu kelas kata dan makna. Sebuah contoh akan memudahkan kita untuk memahaminya. Dalam bahasa Inggris, dari kata dasar girl 
'gadis', bisa dibentuk kata girlish 'genit/seperti anak perempuan' dan girls 'gadis-gadis'. Kata bentukan pertama dengan menambahkan morfem sufiks -ish sebagai pembentuk kata sifat atau ajektiva yang dalam hal ini adalah bentuk ajektiva denominalisasi, dan kata bentukan kedua mendapat imbuhan morfem sufiks $-s$ sebagai pembentuk bentuk jamak. Dari kata girl menjadi girlish adalah proses morfologis derivasional karena merubah identitas leksikal, sementara dari kata girl menjadi girls adalah proses morfologis infleksional karena mempertahankan identitas leksikal. Dalam bahasa-bahasa aglutinatif seperti bahasa Indonesia perbedaan jenis pembentukan kata derivasional dan infleksional tidak sejelas dalam bahasa Inggris, demikian pula dalam bahasa Arab yang bersifat inflektif mempunyai karakter pembentukan kata yang khas. Namun yang perlu diperhatikan dari penjelasan Verhaar adalah bahwa sebagian besar tata bahasawan memakai paradigma untuk daftar alternan-alternan dalam konteks infleksional saja.

Nida (1970: 99) mencirikan perbedaan dua kategori derivatif dan inflektif seperti pada tabel berikut sebagai berikut:

Tabel 1. Perbedaan Derivasi dan Infleksi

\begin{tabular}{|c|c|c|}
\hline Faktor & Derivasi & Infleksi \\
\hline $\begin{array}{l}\text { Perubahan bentuk } \\
\text { dari akar }\end{array}$ & $\begin{array}{l}\text { Merupakan formasi } \\
\text { dalam, muncul lebih } \\
\text { dekat dengan akar } \\
\text { dibanding afiks } \\
\text { infleksional }\end{array}$ & $\begin{array}{l}\text { Merupakan formasi } \\
\text { luar, muncul lebih } \\
\text { jauh dari akar } \\
\text { dibanding dengan } \\
\text { afiks derivasional }\end{array}$ \\
\hline $\begin{array}{l}\text { Variasi pemben- } \\
\text { tukan }\end{array}$ & $\begin{array}{l}\text { Lebih variatif namun } \\
\text { dengan distribusi } \\
\text { terbatas }\end{array}$ & $\begin{array}{l}\text { Kurang bervariasi } \\
\text { namun dalam } \\
\text { distribusi yang luas }\end{array}$ \\
\hline Kelas kata & $\begin{array}{l}\text { Digunakan untuk } \\
\text { menetapkan kata- } \\
\text { kata dalam suatu } \\
\text { kelas kata dan } \\
\text { umumnya }\end{array}$ & $\begin{array}{l}\text { Digunakan untuk } \\
\text { mencocokkan kata- } \\
\text { kata bagi pemakaian } \\
\text { dalam sintaksis } \\
\text { namun tidak }\end{array}$ \\
\hline
\end{tabular}


Morfologi Bahasa Arab: Reformulasi Sistem Derivasi dan Infleksi

\begin{tabular}{lll}
\hline & $\begin{array}{l}\text { mengubah kelas } \\
\text { kata }\end{array}$ & $\begin{array}{l}\text { mengubah kelas } \\
\text { kata }\end{array}$ \\
\hline Distribusi & Kata-kata yang & Kata-kata yang \\
dibentuk melalui & dibentuk melalui \\
derivasi termasuk & infleksi tidak \\
kelas distribusi yang & termasuk kelas \\
sama dengan & distribusi yang sama \\
dengan anggota- & anggota-anggota & anggota yang tidak \\
& dang tidak & kelas yang sama; \\
& diturunkan. & inflikasi relevan \\
& Perubahan yang & secara sintaksis. \\
diakibatkan oleh & derivasi relevan & \\
secara morfologis. & Perubahan \\
& Perubahan & infleksional \\
derivasional & cenderung dibatasi \\
& cenderung tidak & dengan baik, \\
& dibatasi, heterogen & homogen, dan \\
dan hanya & menentukan kelas- \\
menentukan kata- & kata tunggal. & kelas bentuk mayor. \\
\hline
\end{tabular}

Selain itu Ba'dulu dan Herman (2005: 12) juga menerangkan ada tiga aspek yang membedakan antara morfologi derivasional dan morfologi infleksional. Aspek pertama menyangkut masalah produktivitas. Morfologi derivasional biasanya kurang produktif, sedangkan morfologi infleksional sangat produktif. Hal ini berarti bahwa jika kita mengambil afiks infleksional yang biasanya muncul dengan verba, maka kita tidak dapat menambahkannya kepada katakata yang baru dibentuk atau dipinjam. Di lain pihak afiks derivasional tidak dapat digunakan dengan keumuman seperti ini. Afiks derivasional sering tidak dapat digunakan bahkan pada kata-kata yang telah lama diakui.

Aspek kedua adalah dalam wilayah semantis, bahwa afiks derivasional sering memiliki makna leksikal, sedang afiks infleksional biasanya memiliki makna gramatikal. Aspek ketiga yang membedakan antara derivasi dan infleksi adalah 
dalam hal paradigma, bahwa infleksi biasanya disusun dalam suatu paradigma, sedangkan derivasi tidak demikian.

Parera (2007: 21) memandang jenis morfologi derivasi dan infleksi ini sebagai salah satu aspek dari hubungan kata dengan morfem. Pada dasarnya morfem-morfem terikat menurutnya ialah berfungsi membentuk kata. Salah satu akibat dari fungsi pembentukan ini ialah sebuah kata bermorfem jamak atau kata kompleks yang disebut derivasi. Parera memberikan tolak ukur bahwa apabila kata kompleks berdistribusi dan mempunyai ekuivalen dengan kata bermorfem tunggal atau kata tunggal maka bentuk itu disebut derivasi. Dalam hubungan ini secara sisntaksis akan nampak bahwa morfem bebas dasar berada dalam kelas kata yang lain daripada bentuk derivasi tersebut. Dengan ini morfem terikat dapat dikelompokkan berdasar pembentuk kata derivatif.

Aspek kedua menurut Parera dari hubungan antara morfem dan kata ialah bentuk infleksi. Kenyataan ini menunjukkan fungsi yang kedua dari morfem terikat dalam hubungan tersebut. Pengertian infleksi berhubungan pula dengan kata bermorfem jamak. Sama halnya tolak ukur yang dipakai dalam morfologi derivatif, Parera berpandangan jika sebuah proses morfologis menimbulkan satu perubahan bentuk atau kata bermorfem jamak dan bentuk-bentuk tersebut ini secara sintaksis tidak mempunyai ekuivalen dalam distribusi sintaksis dengan sebuah kata bermorfem tunggal maka bentuk ini disebut infleksi.

Pada umumnya perubahan bentuk atau proses morfologis inflektif hanya menyatakan hubungan sintaksis dan tidak membawa pemindahan dari satu kelas kata ke dalam kelas kata yang lain. Distribusi infleksi lebih luas dari distribusi derivasi. Bentuk-bentuk infleksi biasanya memberikan atau menyatakan beberapa kategori ketatabahasaaan seperti tunggal dan jamak, gender, aspek dan waktu, diatesis (bentuk aktif dan pasif), tata tingkat sifat (biasa, lebih, sangat), dan 
beberapa kategori yang mungkin terjadi sesuai dengan kekhasan bahasa tertentu.

Dari uraian-uraian diatas maka dapat diambil kesimpulan bahwa kata kelompok derivasional dan infleksional mempunyai ciri-ciri perilaku lingual sebagai berikut: Pertama, kata-kata derivasional dapat menjadi bentuk dasar baru untuk pembentukan kata-kata yang lain. Bentuk kata baru itu dapat berjenis derivasional maupun infleksional. Kedua, kata derivasional cenderung tidak dapat diruntutkan dalam satu perangkat seperti kata infleksional. Kata derivasional dapat dipandang berada dalam batas antara tata bahasa dan tata leksikon. Ketiga, jika muncul satu morfem derivasional dan satu morfem infleksional untuk membentuk satu kata, morfem derivasional harus didahulukan.

\section{Derivasi dan Infleksi dalam Morfologi Arab}

\section{Perubahan Derivasional}

Dalam rumpun bahasa-bahasa Indo-Eropa seperti bahasa Inggris, pengertian derivasi dan infleksi dapat dikenakan secara konsisten, misalnya bentuk inflektif dapat dilihat dengan jelas pada kata books dari bentuk kata dasar book; stops, stopped, stopping dari kata dasar stop; prettier dan prettiest dari kata dasar pretty (Samsuri, 1982: 198). Juga pada bahasa-bahasa fleksi seperti bahasa Arab, bahasa Latin, dan bahasa Italia pembentukan derivatif dan inflektif lebih kentara (Chaer, 2008: 37). Dalam bahasa Arab, khususnya konsep derivasi, sudah lama terindikasi-meskipun masih bersifat 'amaliyan atau praktis, sejak masa Ibn Abbās', jauh sebelum linguistik umum merumuskan klasifikasi dasar ini.

${ }^{1}$ Ibn 'Abbās memaknai surat Fāthir ayat 1: فاطر السـمَواتوالأرض dari peristiwa orang-orang Arab yang berselisih memperebutkan sebuah sumur. Salah satunya berkata أنـا فطرنهـ 'aku yang memulai menggalinya'. Dari peristiwa ini Ibn 'Abbās mendapati makna فاطر berarti Sang Pencipta 
Derivasi dalam teori linguistik Arab berkaitan dengan konsep isytiqāq (الاشتقاق). Meskipun seringkali isytiqāq sering diartikan sebagai 'etymology' akan tetapi pada kenyataannya penulis melihatnya lebih dominan memainkan peran-peran morfologi derivasional. Al-Khalīl $(170 \mathrm{H})$ dalam al-'Ain menyuguhkan ratusan contoh korelasi derivasional, al-Ashma'ī (216 H) membukukan karyanya Isytiqāq al-Asmā' dan Ibn Duraid (321 H) dengan karyanya al-Isytiqāq. Ibn As-Sarrāj (316 H) menulis Risalāt al-Isytiqāq, tak ketinggalan Az-Zujājī (311 $\mathrm{H}$ ) juga menulis topik ini pada tahun $340 \mathrm{H}$. Namun fenomena lingual ini baru diteorisasikan oleh Ibn Jinnī (392 H) dalam alKhashāish.

Ibn Jinnī (1957: 133-134,165) memulai klasifikasi kategori isytiqāq dalam tradisi gramatika Arab yang sebelumnya masih abstrak ke dalam tiga jenis: al-isytiqāq ash-shaghīr (الاشتقاق الصغير), al-isytiqāq al-kabīr (الاشتقاق الكبير), dan al-isytiqāq al-kubbār (الاشتقاق الكبّار). Secara sederhana isytiqāq shaghīr dapat dipahami sebagai pembentukan kata dari satu bentuk dasar dengan mempertahankan urutan struktur radikal konsonannya. Isytiqāq kabïr dalam terminologi linguistik modern semacam metatesis (القلب المكاني) misalnya kelompok kata - قب - في قَبل - قلب sedangkan isytiqāq kubbār adalah semacam konsep akronim, yaitu pembentukan kata dari dua kata atau lebih, yang dalam teori linguistik Arab dikenal dengan an-na $\underline{h t}$, misalnya bentuk verba بسمل atau nomina بسملة adalah bentuk

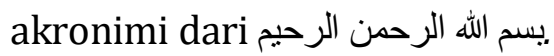

Secara leksikal kata isytiqā $q$ sendiri dalam terminologi linguistik bermakna 'derivasi' dan 'etimologi' (Ba'albaki, 1995: 112). Namun yang perlu diperhatikan kata isytiqāq di sini

yang mulai membuat langit dan bumi, di mana kata فاطر merupakan bentuk partisipel aktif atau فم الفاعل yang diderivasikan dari verba فطر seperti perkataan orang Arab tersebut. Lihat Muhammad Hasan Jabal, 'Ilm alIsytiqāq: Nazhariyan wa Tathbīqiyan. (Kairo: Maktabah al-Adāb, 2005) hlm. 25 . 
tidak serta merta berbanding lurus dengan maksud konsepsi derivasi dalam linguistik umum. Derivasi dalam linguistik Arab lebih dekat pada isytiqāq shaghīr Ibn Jinnī. Pada perkembangan mutakhir teori linguistik Arab, guru besar ushūl allughah Universitas al-Azhar - Hasān Jabāl mengembangkan konsep derivasi dalam teori Arab, ia sependapat dengan Ghulāyainī (1993: 208) ketika mendefinisikan isytiqāq sebagai pembentukan kata baru yang diambil dari base atau bentuk dasar untuk mengekspresikan makna baru sesuai dengan makna leksikal bentuk dasar dengan memperhatikan persesuaian juga urutan radikal konsonannya (Jabal, 2006: 9), misalnya bentuk كاتب - كتاب - كتيبة adalah musytaq atau di-

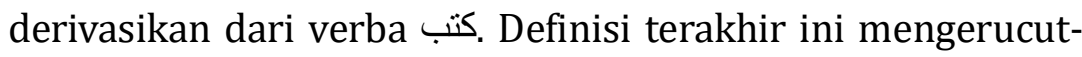
kan pengertian isytiqāq pada titik di mana derivasi memainkan perannya dalam linguistik umum. Kalau kita perhatikan definisi Ibn Jinnī, Jabal dan Ghulāyainī sejalan dengan maksud dari konsep derivasi. Ketika Verhaar menyebutkan terjadinya pergeseran identitas leksikal pada morfologi derivasional, dengan menentukan identitas leksikal tersebut menyangkut dua faktor yaitu bentuk kata dan makna, dua faktor ini pula yang diambil Jabal sebagai indikasi derivasional. Bahkan Jabal memasukkan faktor ketiga berupa persesuaian juga urutan radikal konsonan sebagai indikasi derivasional ini, hal ini mengingat bahasa Arab, berbeda dengan kebanyakan bahasa inflektif lainnya, mengikuti akar konsonan. Pada saat yang sama di sini Jabal memegang konsistensi maksud derivasi dengan menanggalkan dua kategori isytiqāq kabīr dan isytiqāq kubbār dalam morfologi derivasional Arab dan tidak mau terjebak dalam terminologi isytiqāq Ibn Jinnī (Jabal, 2006: 41).

Penulis sependapat dengan rumusan terakhir untuk kemudian menyimpulkan pada akhirnya bahwa morfologi derivasional dalam morfologi Arab modern terwakili secara penuh dalam terminologi isytiqāq ini. Namun selanjutnya Jabal sendiri belum menetapkan demarkasi perpindahan kelas kata 
dalam mengindikasikan perubahan bentuk morfologi ini. Ia menjeneralisir semua pembentukan kata dalam morfologi derivasional. Artinya jika dikatakan wujud perubahan derivasi di sini menjadi jelas, namun di sisi lain perubahan infleksinya menjadi abstrak. Selain bentuk derivasi yang digarap, penulis melihat perlu adanya dasar teoritis pula yang lebih konkret mengenai perubahan infleksional dalam morfologi Arab.

\section{Perubahan Infleksional}

Jika sebelumnya ditemukan bahwa konsep derivasi ekuivalen dengan al-isytiqāq, maka selanjutnya bagaimana dengan konsep infleksi dalam morfologi bahasa Arab. Infleksi dalam bahasa Inggris dikenal dengan inflection yang secara leksikal berarti 'sebuah perubahan' atau 'the changing', dalam bidang gramatika dimaksudkan perubahan bentuk kata, dalam fonologi dimaksudkan perubahan suara (Hornby, 1995: 610), khusus dalam morfologi perubahan ini berbentuk penambahan afiks tertentu atau dengan cara-cara lainnya berdasarkan aturan gramatikan sebuah bahasa (Richards dan Schmidt 2002: 257). Dalam Kamus Besar Bahasa Indonesia infleksi juga diartikan sebagai perubahan bentuk kata yg menunjukkan berbagai hubungan gramatikal (Pusat Bahasa, 2008).

Jadi dari beberapa definisi di atas semuanya menunjukkan bahwa infleksi merupakan sebuah perubahan. Pengertian ini jika ditarik kesejajaran dengan morfologi arab berdekatan dengan kata at-tashriff (التصريف) yang berarti juga 'change' atau 'perubahan', lebih jelas lagi Wehr (1980: 513) juga mengartikannya dengan inflection 'infleksi'; declension 'deklinasi'; dan conjugation 'konjugasi'.

Untuk membedakan antara infleksi, deklinasi, dan konjugasi penulis merujuk pada kategorisasi Verhaar yang menyatakan bahwa morfologi infleksional pada umumnya dituntaskan dalam dua jenis kategori yaitu konjugasi dan 
deklinasi (Verhaar, 2008: 121). Oleh karenanya jika dalam morfologi Arab perubahan infleksional kelas verba dikenal dengan tashrîf al-af'āl (تصريف الأفعال) maka secara terminologi tepat dianalogikan dengan konjugasi verba, sementara pada kelas nomina dikenal dengan tashrïf al-asmā' (تصريف الاسماء) bisa dianalogikan dengan deklinasi nomina.

Gambar 1. Sistematika Derivasi dan Infleksi Morfologi Arab

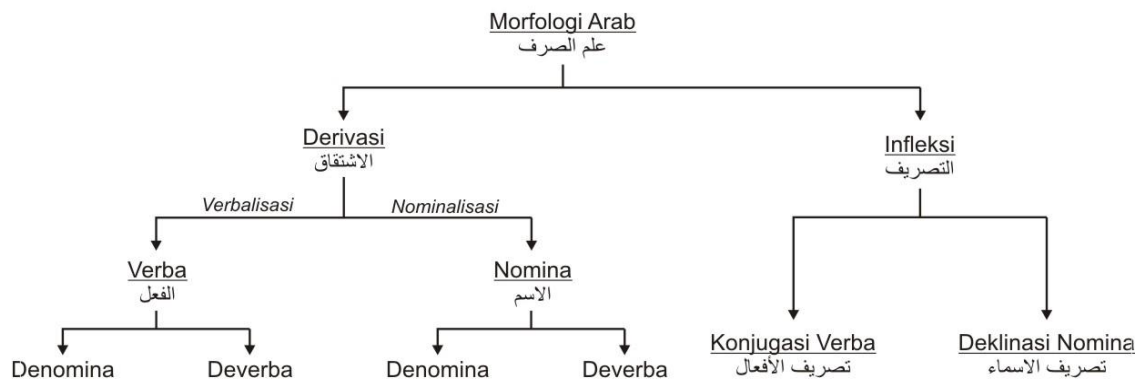

Dari kajian di atas dapat disimpulkan bahwa, bahwa konsepsi morfologi derivasional dalam gramatika Arab selanjutnya dinyatakan masuk dalam terminnologi isytiqāq. Sementara konsep infleksi atau morfologi infleksional di mana proses morfologis yang dijalankan tidak mengubah identitas leksikalnya dalam terminologi gramatika Arab masuk dalam konsepsi at-tashrïf.

Proses derivasional dalam morfologi Arab memperlihatkan sistem dengan logika yang teliti. Proses derivasional di sini dijalankan dalam kerangka root-pattern system atau sistem akar dan pola. Di sini ada kombinasi dua morfem, yaitu morfem akar dan morfem pola, lihat Schramm (1962) dan Ryding (2005). Morfem akar berwujud radikal konsonan berjumlah antara tiga sampai lima konsonan. Di mana morfem akar ini berpautan dengan morfem pola berupa struktur vokal yang menjadi paket model untuk menghidupkan morfem akar tersebut. Morfem pola bisa juga berwujud afiks konsonan yang 
disematkan dengan aturan-aturan tertentu pada morfem akar untuk membangun sebuah bentuk derivasi baru, jadi keduanya baik morfem akar maupun morfem pola adalah morfem terikat yang saling bertautan. Perubahan derivasional semacam ini menjadi ciri khas tradisi bahasa rumpun Semit dan tidak dikenal oleh kebanyakan rumpun bahasa IndoEropa. Misalnya morfem akar S ك - ت - dengan pola pembentuk verba atau verbalisasi_a_a_a menjadi كَتَب '(dia laki-laki telah) menulis', pola pembentuk nomina atau nominalisasi_ $\bar{a}_{-} i_{-}$ كَاتِب 'penulis', pola nominalisasi benda jamak_u_u_ كُبْ 'bukubuku', dan pola nominalisasi dengan prefiks derivasional ma-, ma_ _a_ كَكتَب 'tempat untuk menulis/meja'. Oleh karenanya pemahaman akan pola-pola derivasional ini dalam morfologi Arab bisa sangat efektif membantu percepatan penguasaan kosakatanya.

Gambar 2. Perubahan Derivasi Morfologi Arab

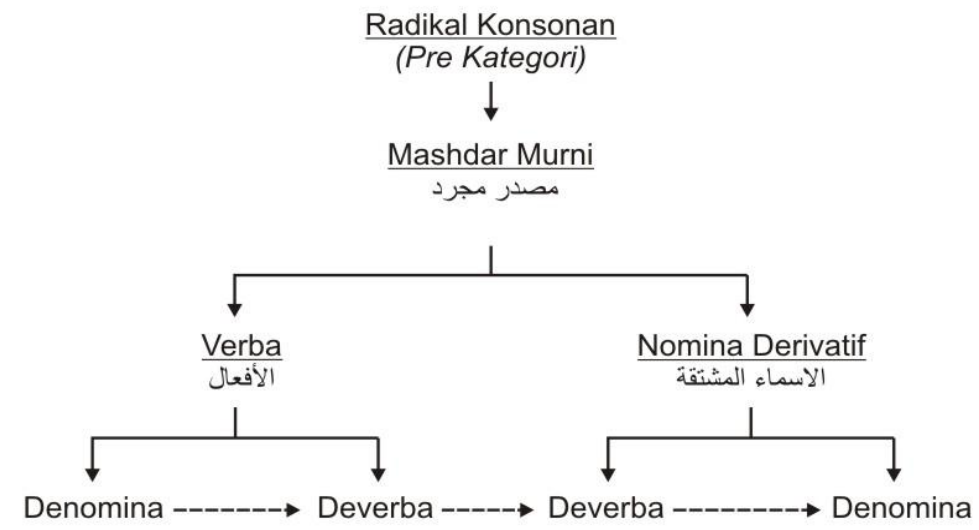

Mengingat morfologi Arab mempunyai akar berbentuk radikal konsonan, bentuk dasar yang paling mendekati akar ini yang dijadikan parameter derivasi. Teori Basrah seperti yang dianut Ghulāyain̄̄ mengatakan bahwa mashdar murni merupakan bentuk dasar dari setiap kata (Ghulāyain̄̄, 1993: 209). Mashdar murni ini dengan kata lain adalah dasar dari semua derivasi kata-kata dalam bahasa Arab 
sementara ia tidak diderivasikan dari kata apapun. Dari mashdar murni ini diderivasikan verba dan nomina derivatif, keduanya mempunyai bentuk denomina dan deverba. Pemetaan pembentukan derivasional dalam bahasa Arab dapat dilihat dalam gambar 2 .

Denomina pada verba berupa verba simpel form 3.I. dari form ini kemudian diderivasikan lima belas bentuk verbalisasi deverba dari form 3.I, jadi form 3.II - 3.XV merupakan verba hasil derivasi atau musytaq dari verba form 3.I. Misalnya dari bentuk dasar form I - دَخَل 'masuk', diderivasikan ke bentuk-

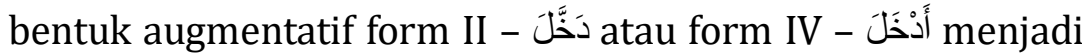
berarti 'memasukkan', atau form V - تَدََّّ berarti 'mencampuri' dan seterusnya (Wehr, 1980: 273). Derivasi ini tentunya tidak membutuhkan persesuaian kategori gramatikal, oleh karenanya Wright (1981) dan para linguis Arab Eropa menyebutnya dengan derived verb karena perubahan bentuk di sini lebih didasari pada kebutuhan aspek semantis tanpa memperhatikan penyesuaian kategori gramatikal. Di sisi lain ini juga bersesuaian dengan parameter Parera bahwa apabila kata kompleks berdistribusi dan mempunyai ekuivalen dengan kata bermorfem tunggal atau kata tunggal maka bentuk itu disebut derivasi (Parera, 2007: 21). Sementara untuk kelas nomina derivatif ada kelompok nomina yang diderivasikan dari verba (اسم مشتق من الأفعال) dan kelompok nomina yang diderivasikan dari nomina (اسم مشتق من الاسماء).

Untuk proses infleksional berkaitan dengan kategori gramatikal. Sebagai analogi dalam bahasa Inggris mengenal tiga kategori gramatikal yaitu: jumlah (tunggal/jamak), kala (lampau/kini/mendatang), dan diatesis (aktif/pasif). Bahasa Arab mengenal lebih banyak kategori gramatikal dibanding dengan bahasa Inggris, ada delapan jenis kategori gramatikal dalam morfologi infleksional bahasa Arab yaitu: kala, persona, diatesis, modus, jenis, jumlah, kasus, definitas. 
Enam kategori diimplementasikan untuk konjugasi verba (kala/aspek, persona, diatesis, modus, jenis, dan jumlah) misalnya verba يَنْصُرُ 'menolong' mencakup kala kini/mendatang (mādlì/mudlāri), persona orang ketiga (ghāib), diatesis aktif (malum), modus indikatif (rafa), jenis maskulin (mudzakkar), dan jumlah tunggal (mufrad), jadi lebih tepatnya يَنْصُرُ diartikan dengan 'dia laki-laki tunggal sedang/akan menolong'.

Empat kategori diimplementasikan untuk deklinasi nomina (jenis, jumlah, kasus, definitas) (Ryding, 2005: 51), misalnya bentuk nomina الكتاب 'sebuah buku' mencakup jenis maskulin (mudzakkar), jumlah tunggal (mufrad), kasus nominatif (marfu), dan definitas definitif (ma'rifah). Dalam proses infleksional setiap kata mengalami persesuaian dengan kategori-kategori gramatikal ini.

\section{Kesimpulan}

Dari pengkajian di atas dapat diambil kesimpulan bahwa dalam morfologi bahasa Arab perubahan derivasional tercakup dalam bahasan al-isytiqãq (الاشتقاق) yang berarti 'derivasi'. Pembentukan kata dalam dalam morfologi derivasional ini berhubungan dengan aspek leksikal untuk kebutuhan pembentukan kata baru. Pembentukan kata secara derivatif dalam bahasa Arab pada kelas nomina memungkinkan terjadinya proses nominalisasi deverba maupun denomina, begitu pula pada kelas verba memungkinkan terjadinya proses verbalisasi denomina maupun deverba. Oleh karenanya dari satu radikal konsonan saja dapat dibentuk kata bentukan yang sangat variatif. Ini kemudian menjadi cirikhas dari morfologi bahasa Arab.

Sedangkan untuk perubahan infleksional tercakup dalam pembahasan at-tashrîf (التصريف) meliputi kelas nomina dalam tashrīfal-asmā' (تصريف الأسماء) dan kelas verba dalam tashrïfalaf'āl (تصريف الأفعال). Pembentukan dalam morfologi infleksional 
ini adalah berkaitan dengan aspek sintaksis dengan penyesuaian kategori-kategori gramatikalnya. Morfologi bahasa Arab mempunyai delapan jenis kategori gramatikal yaitu: kala, persona, diatesis, modus, jenis, jumlah, kasus, definitas. Enam kategori diimplementasikan dalam konjugasi verba meliputi kategori gramatikal kala, persona, diatesis, modus, jenis, dan jumlah. Dan empat kategori diimplementasikan dalam deklinasi nomina meliputi jenis, jumlah, kasus, dan definitas.

\section{Daftar Pustaka}

Anderson, Stephen R. 1985. "Inflectional Morphology". Language Typology and Syntactic Description: Grammatical Categories and the Lexicon. Vol. III. Cambridge: Cambridge University Press.

Ba'albaki, Rohi. 1995. Al-Mawrid: A Modern Arabic English Dictionary. Beirut: Dār al-Ilmi li al-Malāyin.

Ba'dulu, Muis A. dan Herman. 2005. Morfosintaksis. Jakarta: Rineka Cipta.

Bauer, Lauire. 2001. Introducing Linguistic Morphology. Edinburgh: Edinburgh University Press.

Chaer, Abdul. 2008. Morfologi Bahasa Indonesia (Pendekatan Proses), Jakarta, Rineka Cipta.

Ghulāyainī al-, Musthafā. 1993. Jāmi' ad-Durūs al-Arābiya. Beirut: al-Maktabah al-Ashriyah.

Hornby, A.S. 1995. Oxford Advanced Learner's Dictionary. Oxford: Oxford University.

Jabal, Muhammad Hasan. 2005. 'Ilm al-Isytiqāq: Nazhariyan wa Tathbīqiyan. Kairo: Maktabah al-Adāb.

Jinniy, Ibn. 1957. Al-Khashāish. Kairo: Dār al-Ilmiyah. 
Muhammad Aqil Luthfan dan Syamsul Hadi

Nida, Eugene A. 1970. Morphology: The Descriptive Analysis of Words. Michigan: Ann Arbor The University of Michigan Press.

Parera, J.D. 2007. Morfologi Bahasa. Jakarta: Gramedia.

Pusat Bahasa. 2008. Kamus Besar Bahasa Indonesia. Jakarta: Departemen Pendidikan Nasional Republik Indonesia. http://pusatbahasa.diknas.go.id/kbbi/

Richards, Jack C. dan Schmidt, Richard. 2002. Longman Dictionary of Language Teaching and Applied Linguistics. London: Longman.

Robins, R.H. 1992. Linguistik Umum: Sebuah Pengantar. Yogyakarta: Kanisius.

Ryding, Karin C. 2005. A Reference Grammar of Modern Standard Arabic. Cambridge: Cambridge University Press.

Samsuri. 1982. Analisis Bahasa: Memahami Bahasa secara Ilmiah. Jakarta: Erlangga.

Schramm, Gene M. 1962. "An Outline of Classical Arabic Verb Structure". Languge, Vol. 38, No. 4. USA: Linguistic Society of America. www.jstor.org. Wright 1981

Verhaar, J.W.M. 2008. Asas-asas Linguitik Umum. Yogyakarta: Gadjah Mada University Press.

Wehr, Hans. 1980. A Dictionary of Modern Written Arabic. Beirut: Librairie Du Liban.

Wright, William, LL.D. 1981. A Grammar of the Arabic Language. Cambridge: Cambridge University Press. 
THIS PAGE INTENTIONALLY LEFT BLANK 